Accesed on: http://jkb.ub.ac.id/index.php/jkb/article/view/2784

Jurnal Kedokteran Brawijaya Vol. 31, No. 3, Februari 2021, pp. 156-161

Article History: Received 4 Agustus 2020, Accepted 8 Februari 2021

Research Article

\title{
Effects of Propolis Extract Supplementation during Pregnancy on Stress Oxidative and Pregnancy Outcome: Levels of Malondialdehyde, 8-Oxo-2'-Deoxogunosine, Maternal Body Weight, and Number of Fetuses
}

\section{Pengaruh Suplementasi Ekstraks Propolis Selama Hamil Terhadap Tingkat Stres Oksidatif dan Luaran Kehamilan: Kadar Malondialdehyde, 8-Oxo-2'-Deoxyguanosine, Berat Badan Induk dan Jumlah Janin}

\author{
Joko Wahyu Wibowo ${ }^{1}$, Minidian Fasitasari, ${ }^{2}$ Siti Thomas Zulaikhah ${ }^{3}$ \\ ${ }^{1,2}$ Department of Nutrition Faculty of Medicine Universitas Islam Sultan Agung Semarang \\ ${ }^{3}$ Department of Public Health Universitas Islam Sultan Agung Semarang
}

\begin{abstract}
Oxidative stress is related to pregnancy complications that could increase maternal and infant mortality. This study aimed to determine the effect of propolis extract supplementation during pregnancy on oxidative stress level and pregnancy outcomes utilizing Malonedealdehyde (MDA) and 8-Oxo-2'-Deoxogunosine (8-OHdG) levels, maternal body weight, and the average number of fetuses as the parameters. The study was conducted by using a posttest only control group design on 24 pregnant Wistar rats, which were divided into four groups. Group I was control, Group II-IV were the treatment groups given propolis extract of $1.8 \mathrm{mg}, 3.6 \mathrm{mg}$, and $7.2 \mathrm{mg} / 200 \mathrm{gBW} /$ day, respectively. The standard feed given was AIN93G dose of $20 \mathrm{~g} /$ day and distilled water ad libitum. Propolis extract was given using a gastric feeding tube every morning for 20 days. At the end of the treatment, body weight was meisured and blood collected for assessed MDA and 8OHdG levels by ELISA method and then we performed abdominal surgery to count number of fetuses. The result are there were decreasing level of MDA and 8-OHDG by administration of propolis significantly (p<0.05) group: I: 2,04 $\pm 0,091,11$ :

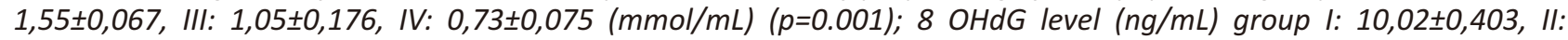

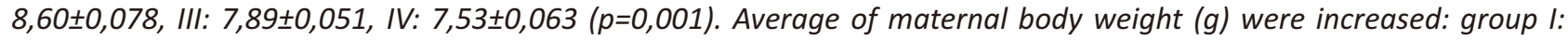

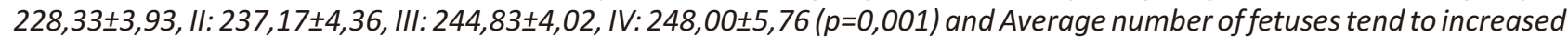

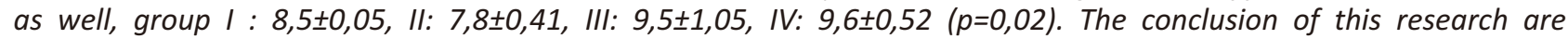
supplementation of propolis extract in pregnant rats can reduce oxidative stress and improve pregnancy outcomes.
\end{abstract}

Keywords: 8-OHdG, maternal body weight, MDA, number offetuses, oxidative stress

\section{ABSTRAK}

Stres oksidatif berkaitan dengan komplikasi kehamilan yang dapat meningkatkan angka kematian ibu dan bayi. Penelitian ini bertujuan untuk mengetahui pengaruh suplementasi ekstrak propolis selama hamil terhadap tingkat stres oksidatif dan luaran kehamilan dengan parameter kadar Malonedialdehyde (MDA) dan 8-Oxo-2'-Deoxygunosine (8-OHdG), berat badan induk, dan jumlah rata-rata janin. Penelitian dilakukan dengan menggunakan desain posttest only control group pada 24 ekor tikus wistar bunting yang dibagi menjadi empat kelompok. Kelompok I sebagai kontrol, Kelompok II-IV adalah kelompok perlakuan yang diberi ekstrak propolis masing-masing 1,8mg, 3,6mg, dan 7,2mg / 200gBB / hari. Pakan standar yang diberikan adalah AIN93G dosis 20g /ekor/ hari dan minum akuades ad libitum. Pemberian ekstrak propolis menggunakan sonde lambung setiap pagi selama 20 hari. Pada akhir pelakuan dilakukan penimbangan berat badan dan pengambilan sampel darah untuk dinilai kadar MDA dan 8-OHdG dengan metode ELISA kemudian dilakukan pembedahan abdomen untuk menghitung jumlah janin. Hasil penelitian didapatkan penurunan yang bermakna kadar MDA (mmol / $\mathrm{mL}$ ) pada pemberian propolis ( $p<0,05)$ kelompok: I: $2,04 \pm 0,091, \mathrm{II}: 1,55 \pm 0,067, \mathrm{III}: 1,05 \pm 0,176, \mathrm{IV}: 0,73 \pm 0,075$ ( $p=$ 0,001); Kadar OHdG (ng / mL) kelompok I: 10,02 $\pm 0,403$, II: 8,60 $\pm 0,078$, III: 7,89 $\pm 0,051$, IV: 7,53 $\pm 0,063$ (p=0,001). Ratarata berat badan induk (g): kelompok I: $228,33 \pm 3,93$, II: $237,17 \pm 4,36$, III: $244,83 \pm 4,02$, IV: $248,00 \pm 5,76$ (p=0,001) dan Rata-rata jumlah janin juga cenderung meningkat, kelompok I: 8,5 $\pm 0,05, \mathrm{II}: 7,8 \pm 0,41, \mathrm{III}: 9,5 \pm 1,05, \mathrm{IV}: 9,6 \pm 0,52$ ( $p=$ 0,02). Kesimpulan dari penelitian ini adalah suplementasi ekstrak propolis pada tikus bunting dapat menurunkan tingkat stres oksidatif dan memperbaiki luaran kehamilan.

Kata Kunci: 8-OHdG, berat badan ibu, jumlah janin, MDA, stres oksidatif

Correspondence: Siti Thomas Z. Department of Public Health Universitas Islam Sultan Agung Semarang, Jl. Kaligawe Raya No.KM, RW.4, Terboyo Kulon, Kec. Genuk, Kota Semarang, Jawa Tengah 50112 Tel. 085727299463 Email: sitithomas@unissula.ac.id 


\section{INTRODUCTION}

Pregnancy is a period in a life of a woman characterized by physiological changes due to the growth and development of the fetal, maternal adaptation to the pregnancy, and maternal preparation for delivery and breastfeeding (1). Environmental changes during intrauterine can increase the risk of degenerative diseases in the future. During pregnancy, if accompanied by obesity, an increase in pro-inflammatory cytokines (2) and also oxidative stress may happen, as a result of increased metabolism, pollution, use of drugs, etc. Oxidative stress is associated with pregnancy complications, such as nausea, vomiting, gestational diabetes, macrosomia, abortion, prematurity, and low birth weight, which could increase the risk of maternal and infant mortality. Oxidative stress during pregnancy is characterized by an increase in MDA levels due to lipid peroxidation that occurs in the placenta and enters the maternal circulation, thus triggering damage to other tissues (1).

Reactive oxygen species (ROS) is a molecule containing one oxygen atom and potentially forms free radicals. In normal quantities and physiological conditions, ROS levels are needed for the cell signaling process and play an important role in maintaining cell function. An excessive ROS level will cause inflammatory process and cytokine production, thereby ROS production becomes excessive if not stopped by increasing the antioxidants (3). Excessive free radicals can damage cell DNA, lipids, and cell proteins. This reactive oxygen species can interact with DNA and causes damage that triggers the loss of cell function.

Antioxidant systems can protect cells from peroxidation reactions, reduce the level of cell damage, enable the processes of cell repair, and help maintain membrane integrity (4). Cell mechanism in repairing the damage due to oxidative stress on DNA is performed in three stages. The first stage is the protection given by the human mutT (hMTH1) enzyme. This enzyme hydrolyzes 8-oxodGTP to 8-oxodGMP and prevents misuse of the triphosphate nucleoside as a substrate for DNA polymerase. The second stage of defense consists of glycoside hydrolase that specifically initiates the cutting by base excision (BER). Lastly, in the third stage, human MutY (hMYH) homolog cuts adenine to repair bonds with 8-oxoGua and excretes the damaged DNA in the form of 8-hydroxy-2deoxyguanosine (8-OHdG). Therefore, $8-\mathrm{OHdG}$ levels can be used as parameters of DNA damage due to oxidative stress (5-7).

In pregnancy, an increase in oxidative stress may occur, which is marked by an increase in lipid peroxide levels associated with metabolic syndrome components, such as insulin resistance, hypertriglyceridemia, and increased inflammatory cascade (4). Gestational diabetes and macrosomia are associated with increased oxidative stress (1). Free radicals are needed for the development of the embryo, but an excessive amount will cause oxidative stress associated with pregnancy complications, such as preeclampsia and hyperemesis. Fe supplementation during pregnancy contributes to an increase in oxidative stress in pregnant women, characterized by an increase in maternal plasma MDA levels and the placenta (4).

Antioxidant supplementation during pregnancy gives mixed results because of varied types and preparations used (4). Propolis is widely researched and gives positive results in reducing oxidative stress levels. Propolis is a bee product that has various health benefits, such as antioxidant, antimicrobial with broad-spectrum, antivirus, anti-parasite, anti-inflammatory, anti-tumor, antifungal, hepatoprotection, cytotoxic, anti-bacterial, antianemia, and immunomodulator (8-11). Anti-tumor and cytotoxic properties allow propolis to have a negative effect when consumed by pregnant women (10), but studies on propolis supplementation in pregnancy are still limited.

Analysis from various propolis samples showed approximately 300 different components of active substances. The potency of the biological activity of these active substances can be classified based on the levels of phenolic components, such as flavonoids in several forms (flavonols, flavones, flavonones, dihydroflavonols, and chalcones), terpenes, beta-steroids, aromatic aldehydes, and alcohol (9). The mechanism of the polyphenol antioxidant contained in propolis is because of its ability to scavenge reactive oxygen species (ROS) and radical reactive nitrogen species (RNS) to reduce xanthine oxidase reaction, bind to metal ions that play a part in the formation of free radicals, and cut the cascade of peroxidation reactions lipids and synergism with other antioxidants (9). Propolis also contains micronutrients that play a role in antioxidant systems, which are vitamins $(A, C$, $\mathrm{E}, \mathrm{B} 1, \mathrm{~B} 2$, and $\mathrm{B} 6$ ) and minerals ( $\mathrm{Cu}, \mathrm{Zn}, \mathrm{Mn}, \mathrm{Fe}, \mathrm{Na}, \mathrm{Ca}$, and $\mathrm{Mg}$ ). The content of vitamins and minerals in Indonesian Propolis is higher than Brazilian Propolis, except the levels of vitamin A and enzyme succinate dehydrogenase $(8,10)$. The protective effect of propolis on pregnancy outcome and oxidative stress is possible because of the synergistic effect of the phytochemical content of propolis (12). The effect of low dose propolis of $380 \mathrm{mg} / \mathrm{kg} /$ day does not have a negative effect on pregnancy, whereas a high dose of $1400 \mathrm{mg} / \mathrm{kg} /$ day gives an effect of losing the weight and length of the body (10).

\section{METHOD}

This 24study was an experimental study with post-test only control group design on 24 pregnant Wistar rats divided into four groups containing six rats. Group I was a control group that received a standard diet, AIN93G feed at a dose of $20 \mathrm{mg} / \mathrm{rat} /$ day, Group II, III and IV received a standard diet and propolis extract of $1.8 \mathrm{mg}, 3.6 \mathrm{mg}$, and $7.2 \mathrm{mg} / 200 \mathrm{gBW} /$ day, respectively; and were given distilled water ad libitum. The propolis extract used was Propoelix produced by PT. Phytochemindo Reksa, Bogor, Indonesia. The administration of propolis extract was done using a gastric feeding tube every morning for 20 days after pregnancy was indicated by vaginal plugs after the rat have been mated (13). The gestation period in rats was 21 to 23 days, so the propolis extract treatment was stopped on the $20^{\text {th }}$ day, followed by weighing and taking blood samples for the examination of MDA levels by using the ELISA (EnzymeLinked Immunosorbent Assay). MDA examination was performed by using a spectrophotometer at a wavelength of $532 \mathrm{~nm}$. 8-OHdG levels were examined by using the ELISA method and then performed abdominal surgery to acount number of fetuses. All of these experimental study were conducted in the Laboratory of Food and Nutrition Study Center, Gadjah Mada University, Yogyakarta.

\section{RESULT}

On the day $1,5,11,16$ and 20 , data of maternal body weight showed a normal distribution and was homogeneous ( $p$ > 
Table 1. Average maternal body weight based on graup and treatment duration

\begin{tabular}{|c|c|c|c|c|c|}
\hline \multirow{2}{*}{ Body Weight (g) } & \multicolumn{4}{|c|}{ Dose of propolis extract/200g BW/day (mg) } & \multirow{2}{*}{$\mathbf{p}$} \\
\hline & Group I (No Propolis) & Group II $(1,8)$ & Group III $(3,6)$ & Group IV $(7,2)$ & \\
\hline day 1 & $177.67 \pm 3.83$ & $177.00 \pm 4.20^{* *}$ & $177.83 \pm 3.19$ & $178.17 \pm 5.15$ & 0.968 \\
\hline day 5 & $185.17 \pm 4.26$ & $186.33 \pm 4.37^{* *}$ & $187.17 \pm 3.92$ & $190.83 \pm 5.04$ & 0.172 \\
\hline day 11 & $199.00 \pm 3.99$ & $203.33 \pm 4.32 * *$ & $206.50 \pm 3.78$ & $209.67 \pm 5.57$ & $0.003 *$ \\
\hline day 16 & $213.00 \pm 4.05$ & $220.84 \pm 4.07^{* *}$ & $225.83 \pm 4.02$ & $229.33 \pm 5.35$ & $0.001^{*}$ \\
\hline day 20 & $228.33 \pm 3.93$ & $237.17 \pm 4.36 * *$ & $244.83 \pm 4.02$ & $248.00 \pm 5.76$ & $0.001 *$ \\
\hline
\end{tabular}

Note: * Oneway Anova, ${ }^{* *} \mathrm{~g}$

0.05), so the ANOVA test could be performed. The ANOVA test results maternal body weight based on treatment duration (Table 1) showed no significant differences on day 1 and 5 of treatment. In contrast, on day 11,16, and 20 , there were significant differences between the control group compared to the treatment groups that received propolis extract supplementation. There were no significant differences in the mean weight on the first day $(p=0.968)$, while the mean weight of the $20^{\text {th }}$ day as a result of the ANOVA test revealed significant differences among the treatment groups $(p=0.001)$. The highest mean body weight was found in the group receiving propolis supplementation at a dose of $7.2 \mathrm{mg} / 200 \mathrm{~g} \mathrm{BW} /$ day.

The level of oxidative stress in the group of pregnant rats receiving a standard diet only was significantly higher than the treatment groups that received propolis extract supplementation during pregnancy (Table 2). This is indicated by lower MDA and 8-OHdG levels in the treatment groups compared to control. The higher the level of propolis given, the lower the MDA and 8-OHdG levels.

Table 2. MDA level, 8-OHdG level, and the number of fetuses based on treatment groups

\begin{tabular}{lccccc}
\hline \multirow{2}{*}{ Parameter } & \multicolumn{5}{c}{ Dose of propolis extract/200g BW/day (mg) } \\
\cline { 2 - 5 } & Group I & Group II & Group III & Group IV & \\
\hline $\begin{array}{l}\text { MDA } \\
(\mathrm{mmol} / \mathrm{mL})\end{array}$ & $2.04 \pm 0.091$ & $1.55 \pm 0.067$ & $1.05 \pm 0.176$ & $0.73 \pm 0.075$ & $0.001^{*}$ \\
$\begin{array}{l}8-\mathrm{OHdG} \\
(\mathrm{ng} / \mathrm{mL})\end{array}$ & $10.02 \pm 0.403$ & $8.60 \pm 0.078$ & $7.89 \pm 0.051$ & $7.53 \pm 0.063$ & $0.001^{*}$ \\
$\begin{array}{l}\text { Number of } \\
\text { fetuses }\end{array}$ & $8.5 \pm 0.05$ & $7.8 \pm 0.41$ & $9.5 \pm 1.05$ & $9.6 \pm 0.52$ & $0.02^{* *}$ \\
\hline
\end{tabular}

Note: * Mann Whitney, ${ }^{* *}$ Kruskal Wallis

\section{DISCUSSION}

\section{Stres Oxidative Level}

This study show that MDA levels in the groups that received propolis extract supplementation were lower than those in the control group that only received a standard diet. This situation shows the benefits of propolis extract supplementation in reducing the level of lipid peroxidation, which can trigger oxidative stress. An increase in propolis dosage shows an increase in the ability of the antioxidant system of the body to reduce oxidative stress. Lipid peroxidation due to ROS is a fast reaction that occurs because of oxidative stress, the lipid bilayer contained in the cell membrane is quickly damaged so that ROS and other prooxidants can easily leave the cell. Malondialdehyde is a result of lipid peroxidation which can be used as a marker for oxidative stress (3).
The level of oxidative stress in pregnancy was inversely proportional to the dose of propolis extract which is likely because the content of active substances in propolis, especially phenolic and micronutrient components, can increase the antioxidant status. The components of propolis consist of $50-60 \%$ resin and balm (including phenolic compounds), 30-40\% wax and fatty acids, 5-10\% of essential oils, $5 \%$ pollen, and about $5 \%$ other substances including amino acids, and micronutrients. The components of the vitamin in propolis that consist of thiamine, riboflavin, pyridoxine, $C$, and $E$ are also known to play a role in the antioxidant defense mechanism. Propolis contains more than 300 polyphenol compounds, terpenoids, steroids, sugars, amino acids, and phenolic compounds that are believed to be responsible for the ability of antioxidant activity. The total phenolic content of propolis extract per gram is equivalent to $30-200 \mathrm{mg}$ gallic acid (GAE), and flavonoid content ranges from 30-70mg quercetin $(\mathrm{QE}) / \mathrm{g}$, and the ability to bind to $\mathrm{DPPH}$ free radicals (1,1-Diphenyl-2-Picrylhydrazyl) ranges from 20 to $190 \mu \mathrm{g} / \mathrm{mL}(14)$. The nutritional content in propolis extracts which is proven to be able to neutralize or stop the formation of free radicals has the potential to prevent mutagenesis and DNA damage (7)

This study is in accordance with Kaya's research which found that MDA and GSH levels were significantly lower in the group of mice treated with propolis $(p<0.001)(15)$. Similarly, previous study by Nina et al., which showed a decrease in the level of oxidative stress which was marked by a decrease in lipid peroxidation in the testes and epididymis in diabetic rats that received propolis malaya supplementation (16). Propolis extract supplementation during pregnancy was better at reducing oxidative stress than iron-folate supplementation during pregnancy, which was characterized by a higher average MDA level in the iron-folate supplementation group compared to propolis extract supplementation, although the mean body weight was not different (17). Propolis has the capacity to suppress ROS through two different mechanisms, first the presence of caffeic acid phenethyl ester (CAPE) which can activate the transcription factor NrF2 which is a regulatory protein for antioxidant defense systems and increase in antioxidant enzymes such as heme oxygenase-1, phase II detoxification enzymes, and enzymes that play a role in GSH metabolism, so as to increase cellular antioxidant capacity. The second mechanism is to neutralize ROS through the ability of phenol and flavonoid components such as quercetin, CAPE, $p$ vanillin, p-coumaric acid, apigenin, and cinnamic acid found in propolis. CAPE also could inhibit the activation of the transcription factor pathway Natural factor-kB(NFkB) $(9,18)$.

Previous studies support the effect of propolis on lipid peroxidase. Study by Mujica found that benzyl caffeate isolated from propolis is able to inhibit the formation of 
lipid peroxide and a very low dose of propolis ethanol extract has the capacity to reduce lipid peroxidation and able to increase GSH levels, reduce TBARS levels significantly, and increase HDL-c from $53.9 \pm 11.9 \mathrm{mg} / \mathrm{dL}$ to $65.8 \pm 16.7 \mathrm{mg} / \mathrm{dL}$ compared to control group on propolis use for 90 day (9). Atefeh's study concurred that the provision of Iranian propolis extract could significantly reduce MDA levels in ovarian tissue (19). Provision of propolis at a dose of $50 \mathrm{mg} / \mathrm{kgBW}$ and $100 \mathrm{mg} / \mathrm{kgBW}$ to rats induced by diabetes for 6 weeks was able to reduce oxidative stress, marked by a decrease in levels of malondialdehyde MDA in liver and pancreatic tissue, increase the antioxidant system, glutathione (GSH), superoxide dismutase (SOD), catalase (CAT) and total antioxidant capacity (TAC), reduce proinflammatory cytokines such as C-reactive Protein (CRP), interleukin 10 (IL-10) and transformation growth factor $\beta$ (TGF- $\beta$ ) (20).

The results of this study also support previous research on the benefits of propolis in reducing oxidative stress levels conducted by Hesami which showed that the administration of Iranian propolis was able to increase the antioxidant system and decrease the level of LDL oxidation in type 2 diabetic patients(21). Extract of aqueous propolis has a significant antioxidant effect and is protective against the effects of oxidative stress on pancreatic beta cell cultures (22). Finding of this study which showed that propolis extract supplementation reduce the $8-\mathrm{OHdG}$ level suggests that propolis extract supplementation reduces the level of oxidative stress in DNA. Level of 8OHdG as an indicator of DNA damage due to oxidative stress, the DNA repair mechanism is carried out by the enzyme 8-OxoG DNA glycosylase (OGG1). Increased OGG1 activity is characterized by increased OGG1 acetylation in response to oxidative stress (23).

\section{Outcome of Pregnancy}

\section{Maternal Body Weight}

This study shows a significant difference in mean body weight, especially in the middle and late stages of pregnancy, marked by significant differences in body weight on days 11,16 and 20 while on the first and fifth day there was no significant difference. A significant increase in body weight in the group that received propolis extract supplementation compared to the control group was reveals in this study. This situation indicates the influence of nutrition in regulating homeostasis in energy synthesis during pregnancy. These results are in accordance with Khalaf's research, who found that subjects with propolis supplementation $500 \mathrm{mg}$ twice a day for 2 months showed a significant increase in body weight and HDL-c levels (24). Furthermore, studies conducted on Onchorhynchus mykiss fish supplemented with $1 \%$ propolis extract in their feed showed increased growth at the end of the treatment compared to the control group (25). These results support the theory that nutritional factors which are part of the environment can change phenotypic expression by epigenetic modifications to DNA/histone/miRNA (26). The nutrients contained in propolis extract can increase the effectiveness of metabolism which is marked by an increase in body weight. During pregnancy there are metabolic adaptations to prepare the environment to support fetal growth and preparation for the lactation process. Studies on rat peri uterine adipose tissue demonstrated the conversion of glucose to fatty acids and glycerol. Energy is required during pregnancy especially up to day 20 of rat gestation. There were changes in maternal lipid metabolism that occurred in the 1st and 2 nd trimesters associated with fat accumulation in the adipose tissue and de novo lipogenesis (27).

\section{Number of Fetuses}

Result of this study proved that propolis extract supplementation can improve the intrauterine environment which indicated by the fact that the average number of fetuses in the supplementation group, especially the doses of $3.6 \mathrm{mg} / 200 \mathrm{gBW} /$ day and $7.2 \mathrm{mg} / 200 \mathrm{gBW} /$ day was higher than the control group. Polyphenols such as curcumin, gallic acid, epicatechin, and some flavonoids in relatively low doses have the capacity to reduce some of the proinflammatory response by modulating HAT and HDAC activity (28). Propolis supplementation resulting in better epigenetic modifications during the critical period in the womb, and these results are expected to support the long-term health of the child (29).

Polyphenol contained in propolis can protect normal cells against oxidative stress, through the induction of Glutathione S-transferase P1 (GSTP1) as the main part of Glutathione S-transferases (GSTs) which play a role in phase II detoxification in the metabolic process of xenobiotic substances. GSTP1 is an enzyme that catalyzes the conjugation of glutathione and the formation of thioester bonds against various electrophilic substances in the detoxification process of xenobiotics. GSTP1 found in chromosome 11q13 which has 4 allele variants. Adequate expression of GSTP1 is essential for maintaining normal cell function. GSTP1 expression and activity are regulated by transcriptional activity and are suppressed by posttranslational modification and are influenced by the redox status of the cells. Oxidative stress decreases GSTP1 activity by forming disulfide bonds between cystine 47 and $101(30)$.

Propolis extract contains vitamin C that plays a role in the antioxidant system which works directly to scavenge the ROS/RNS produced during normal cellular metabolism. The antioxidant mechanism of ascorbic acid is based on the donation of hydrogen atoms to lipid radicals, singlet oxygen, and removing oxygen molecules $(31,32)$. Vitamin C is a 'radical scavenger' for superoxide and peroxyl radicals, hydrogen peroxide, hypo chloric acid, and air pollutant oxidants (33). Vitamin C also plays a role in the process of epigenetic modification, especially demethylation of DNA and histones, activates the Ten Eleven Translocation (TET) enzyme which could restore methyl groups from DNA and histone methylation, regulate DNA demethylation as a TET dioxygenase cofactor or increase $\mathrm{Fe}^{+}$recycling and regulate demethylation (34,35). Vitamin A and vitamin C contained in propolis extract enhance the differentiation of pluripotent stem cells and promote the erasure of epigenetic memory (35)

Epigenetic modification during pregnancy can be due to interactions between genetic and environmental factors including diet (36). Diet affects various biological activities in the body, including signal transduction mediated by nuclear receptors or the presence of transcription factors such as NF-kB, cell proliferation and differentiation, cell cycle progression, DNA repair, induction of apoptosis and cell aging. Polyphenols, vitamins and minerals in propolis extraction can affects the gut composition of the microbiota and its metabolite products, which are 
important mediators in the interaction between diet and the epigenome (37).

Our findings concluded that supplementation of propolis extract during rat pregnancy at doses of $1.8 \mathrm{mg}, 3.6 \mathrm{mg}$, and $7.2 \mathrm{mg} / 200 \mathrm{~g}$ BW was able to reduce the level of oxidative stress, marked by a significant decrease in MDA levels. The ability to reduce MDA levels is directly proportional to the dose of supplementation. Propolis extract supplementation during pregnancy was able to significantly reduce the DNA damage due to free radicals which was characterized by a decrease in 8-OHdG levels . Maternal weight gain differed significantly among the groups that received propolis extract supplementation compared to the control group on days 11, 16 and 20 of pregnancy. There was an increasing trend in the number of fetuses in the group treated with propolis extract supplementation at doses of $3.6 \mathrm{~g}$ and $7.2 \mathrm{~g} / 200 \mathrm{gBW} /$ day even though it was still a normal fetus in rats.

\section{CONFLICT OF INTEREST}

There is no conflict of interest in this study

\section{ACKNOWLEDGMENTS}

We would like to express our gratitude to the Dean of the Faculty of Medicine, Sultan Agung University, Sultan Agung Islamic University Semarang through the LPPM who has funded this research, Nabila, Pingkan, and Mr.

\section{REFERENCES}

1. Samir D, Dalal D, and Noura A. Study of Oxidative Stress during Pregnancy. Global Journal of Pharmacy and Pharmaceutical Sciences. 2018; 4(5): 1-4.

2. Sen S, Iyer C, and Meydani SN. Obesity During Pregnancy Alters Maternal Oxidant Balance and Micronutrient Status. Journal of Perinatology Nature Publishing Group; 2014; 34(2): 105-111.

3. van de Lagemaat EE, de Groot LCPGM, and van den Hauvel EGHM. Vitamin B 12 in Relation to Oxidative Stress: A Systemtic Review. Nutrients. 2019; 11(2): 1-16.

4. Duhig K, Chappell LC, Shennan AH. Oxidative Stress in Pregnancy and Reproduction. Obstetric Medicine. 2016; 9(3): 113-116.

5. Dani IC and Budiawan. Pembentukan 8-OHdG dari Zat Toksik Pemicu Radikal Bebas Abstrak. Pharmaceutical Science \& Research. 2015; 2(1): 32-46.

6. Jin L, Yang $\mathrm{H}, \mathrm{Fu} J$, Xue X, Yao L, and Qiao L. Association between Oxidative DNA Damage and the Expression of 8-Oxoguanine DNA Glycosylase 1 in Lung Epithelial Cells of Neonatal Rats Exposed to Hyperoxia. Molecular Medicine Reports. 2015; 11(6): 4079-4086.

7. Roszkowski K. Oxidative Stress In Pregnant Women. Archives of Perinatal Medicine. 2013; 19(3): 150-155.

8. Halim E, Hardinsyah, Sutandyo N, Sulaeman A, Artika M, Agung AD, and Harahap Y. Kajian Bioaktif dan Zat Gizi Propolis Indonesia dan Brasil. Jurnal Gizi dan Pangan. 2012; 7(1): 1-7.
Yuliyanto who helped in the research process.

\section{ABBREVIATIONS}

$\begin{array}{ll}\text { CAPE } & : \text { Caffeic acid phenethylester } \\ \text { CAT } & : \text { Catalase } \\ \text { CRP } & : \text { C-reactive Protein } \\ \text { DM } & : \text { Diabetes Mellitus } \\ \text { DPPH } & : \text { (1,1-Diphenyl-2-Picrylhydrazyl } \\ \text { GSH } & : \text { Reduced glutathione } \\ \text { GSTP1 } & : \text { Glutathione S-transferase P1 } \\ \text { HAC } & : \text { Histon acetylase } \\ \text { HAT } & : \text { Histon Acetyl Transferase } \\ \text { HDAC } & : \text { Histone deacetylase } \\ \text { IL-10 } & : \text { interleukin 10 } \\ \text { LDL } & : \text { Low Dencity Lipoprotein } \\ \text { LPPM } & : \text { Lembaga Penelitian dan Pengabdian } \\ \text { Masyarakat } & \\ \text { MDA } & : \text { Malondialdehyde } \\ \text { NF-KB } & : \text { Nuclear Factor-kappaB } \\ \text { OGG1 } & : \text { 8-OxoG DNA glycosylase1 } \\ \text { 8-OHdG } & : \text { 8-oxo-2'-deoxogunosine } \\ \text { ROS } & : \text { Reactive oxygen species } \\ \text { SOD } & : \text { Superoxide dismutase } \\ \text { TAC } & : \text { Total antioxidant capacity } \\ \text { TBARS } & : \text { Thiobarbituric acid reactive substance } \\ \text { TGF- } \beta & : \text { Transformation growth factor } \beta \\ \text { TET } & : \text { Ten-Eleven Translocation }\end{array}$

9. Mujica V, Orrego R, Pérez J, et al. The Role of Propolis in Oxidative Stress and Lipid Metabolism: A Randomized Controlled Trial. Evidence-based Complementary and Alternative Medicine. 2017; 2017: 1-11.

10. Fikri AM, Sulaeman A, Handharyani E, Marliyati SA, and Fahrudin FE. The Effect of Propolis Administration on Fetal Development. Heliyon. 2019; 5(10): 1-7.

11. Kabbash A, El-aasr M, Mansour FR, Hasegawa M, Ataka S, and Yagi A. Nature Treasure: Aloe Vera and Bee-Products. Journal of Gastroenterology and Hepatology Research. 2018; 7(4): 2612-2631.

12. Usman UZ, Bakar ABA, and Mohamed M. Propolis Improves Pregnancy Outcomes and Placental Oxidative Stress Status in Streptozotocin-Induced Diabetic Rats. BMC Complementary and Alternative Medicine. 2018; 18(1): 1-7.

13. Hamid HY and Zakaria ZAB. Reproductive Characteristics of the Female Laboratory Rat. African Journal of Biotechnology. 2013; 12(19): 2510-4251.

14. Badehnoosh B, Karamali K, Zarati M, et al. The Effects of Probiotic Supplementation on Biomarkers of Inflammation, Oxidative Stress and Pregnancy Outcomes in Gestational Diabetes. The Journal of Maternal-fetal \& Neonatal Medicine. 2018; 31(9): 1128-1136.

15. Kaya E, Yilmaz S, and Ceribasi S. Protective Role of Propolis on Low and High Dose Furan-Induced Hepatotoxicity and Oxidative Stress in Rats. Journal of Veterinary Research. 2019; 63(3): 423-431.

16. Nna VU, Bakar ABA, Ahmad A, Eleazu CO, and 
Mohamed M. Oxidative Stress, NF- $\kappa$ B-Mediated Inflammation and Apoptosis in the Testes of Streptozotocin-Induced Diabetic Rats: Combined Protective Effects of Malaysian Propolis and Metformin. Antioxidants. 2019; 8(10): 1-23.

17. Wahyuwibowo J, Aziz A, Safitri E, Fasitasari M, and Zulaikhah ST. Iron-Folate Supplementation during Pregnancy for Prevent Oxidative Stress in Pregnant Rats: Level of MDA, Creatinine, Glucose, Erythrocite, Blood Pressure, Body Weight and Num. Pharmacognosy Journal. 2020; 12: 186-191.

18. Seven PT, Yilmaz S, Seven I, et al. The Effects of Propolis in Animals Exposed Oxidative Stress. In: Lushchak V (Ed). Oxydative Stress-Environmental Induction and Dietary Antioxidants. Rijeka, Croatia: InTech Europe; 2012; pp.267-88.

19. Arabameri A, Sameni $\mathrm{H}$, and Bandegi A. The Effects of Propolis Extract on Ovarian Tissue and Oxidative Stress in Rats with Maternal Separation Stress. International Journal of Reproductive Biomedicine. 2017; 15(8): 509-520.

20. Hemieda FAE, El-Kholy WM, El-Habibi, and El-Sawah SG. Influence of Propolis on Oxidative Stress, Inflammation and Apoptosis in StreptozotocinInduced Diabetic Rats. International Journal of Advanced Research. 2015; 3(7): 831-845.

21. Hesami S, Hashemipour S, Shiri-Shahsavar MR, Koushan Y, and Haghighian HK. Administration of Iranian Propolis Attenuates Oxidative Stress and Blood Glucose in Type II Diabetic Patients: A Randomized, Double-Blind, Placebo-Controlled, Clinical Trial. Caspian Jurnal of Internal Medicine. 2019; 10(1): 48-54.

22. Carter RJ and Parsons JL. Base Excision Repair, a Pathway Regulated by Posttranslational Modifications. Molecular and Cellular Biology. 2016; 36(10): 1426-37.

23. Wehinger S. Propolis Extracts Protects Pancreatic Beta Cells from Oxidative Stress in Vitro. Proceeding Scientific Program $15^{\text {th }}$ International Congress on Advances in Natural Medicines Nutraceuticals \& Neurocognition. Berlin, Germany, July 8-9, 2019.

24. Khalaf DA and Thanoon IAJ. Effects of Bee Propolis on Blood Pressure Record and Certain Biochemical Parameter in Healthy Volunteers. Annals of the College of Medicine Mosul. 2018; 40(1): 20-26.

25. Choobkar N, Kakoolaki S, Mohammadi F, and Rezaeimanesh M. The Effect of Dietary Propolis and Pollen Extracts on Growth Performance and Haematological Responses of Rainbow Trout (Onchorhynchus Mykiss). Iranian Journal of Aquatic Animal Health. 2017; 3(1): 16-25.
26. Schütz LF, Bernardo J, Le $\mathrm{M}$, et al. Application of Nutraceuticals in Pregnancy Complications: Does Epigenetics Play a Role? In: Patel V and Preedy V (Eds). Handbook of Nutrition, Diet, and Epigenetics. Berlin, Jerman: Springer; 2019; p. 1959.

27. Zeng Z, Liu F, and Li S. Metabolic Adaptations in Pregnancy: A Review. Annals of Nutrition \& Metabolism. 2017; 7(1): 59-65.

28. Kiss AK. Polyphenols and Histone Acetylation. In: Patel V and Preedy V (Eds). Handbook of Nutrition, Diet, and Epigenetics. Berlin, Jerman: Springer; 2019; p. 1977.

29. Carter LG, Qi NR, de Cabo R, and Pearson KJ. Maternal Exercise Improves Insulin Sensitivity in Mature Rat Offspring. Medicine and Science in Sports and Exercise. 2013; 45(5): 832-840.

30. Thakur VS and Gupta S. Plant Polyphenols as Epigenetic Modulators of Glutathione S-Transferase P1 Activity. In: Sarkar FH (Ed). Epigenetics and Cancer. Cleveland: Springer; 2013; p. 231-244.

31. Akbari A, Jelodar G, Nazifi S, and Sajedianfard J. An Overview of the Characteristics and Function of Vitamin $C$ in Various Tissues: Relying on its Antioxidant Function. Zahedan Journal of Research in Medical Sciences. 2016; 18(11): 1-9.

32. Sisein EA. Biochemistry of Free Radicals and Antioxidants. Scholar Academic Journal of Biosciences (SAJB). 2014; 2(2): 110-118.

33. Carr $A C$ and Maggini S. Vitamin $C$ and Immune Function. Nutrients. 2017; 9(11):1-25.

34. Pehlivan FE. Vitamin C: An Epigenetic Regulator. London: Intechopen; 2018; p.1-12.

35. Hore TA, von Meyenn $F$, Ravichandran $M$, et al. Retinol and Ascorbate Drive Erasure of Epigenetic Memory and Enhance Reprogramming to Naïve Pluripotency by Complementary Mechanisms. Proceedings of the National Academy of Sciences of the United States of America. 2016; 113(43): 1220212207.

36. Chen Z, Gong L, Zhang P, et al. Epigenetic DownRegulation of Sirt 1 Via DNA Methylation and Oxidative Stress Signaling Contributes to the Gestational Diabetes Mellitus-Induced Fetal Programming of Heart Ischemia-Sensitive Phenotype in Late Life. International Journal of Biological Sciences. 2019; 15(6): 1240-1251.

37. Gerhauser C. Impact Of Dietary Gut Microbial Metabolites On The Epigenome. Philosophical Transactions of the Royal Society of London. 2018; 373(1748): 1-13 